\title{
Denial, Deferral and Translation
}

\author{
Dynamics of Entangling and Disentangling State \\ and Non-state Law in Postcolonial Spaces
}

TOBIAS BERGER

\subsection{Introduction}

Legal entanglements unfold in a curious space. They emerge in-between different sets of norms, which are neither fully integrated nor kept entirely apart. ${ }^{1}$ This position in-between various sets of norms is inherently unstable, so that legal entanglements need ardent work of creation, maintenance and constant renewal. Entanglements thus need to be made and unmade by specific actors who are situated in historically shaped yet malleable contexts where different sets of norms overlap and coincide. This chapter focuses on the ways in which different actors entangle international, state and non-state law in postcolonial societies. While undoubtedly a very heterogeneous category that unavoidably escapes reductionist attempts at homogenization, I argue that those places where colonial powers institutionalized plural legal orders as explicit strategies for the consolidation of their rule constitute a privileged site for the investigation of entangled legalities. It is from these sites that systemic images of law, as they have been problematized in Chapter 1, have been forcefully attacked. As Renisa Mawani argues, 'Law, in all of its plurality including Western, customary, and personal law - is conventionally viewed as geographically situated and territorially bound to national and imperial polities. What the comparative and transnational turn has revealed is that law was also itinerant, moving with imperial authorities and colonial subjects, and connecting imperial jurisdictions in the process. $^{.2}$ Itinerant laws have thus produced historically grown legal

${ }^{1}$ See the definitional discussion in Chapter 1.

2 R. Mawani, 'Law and Colonialism', in A. Sarat and P. Ewick (eds), The Handbook of Law and Society (Wiley-Blackwell, 2015), pp. 417-32, at p. 426. 
entanglements affecting socio-legal dynamics in most of the world today. Yet laws hardly ever travel by themselves.

This chapter consequently analyses (some of) the actors that make law move and the dynamics in which they seek to make and unmake certain legal connections. Focusing on judges and activists of non-governmental organizations (NGOs), it identifies three modes in which dynamics of distancing and approximation between different sets of norms can unfold: denial, deferral and translation. Whereas denial refers to a state where empirically existing entanglements are acknowledged but their legal as well as normative validity is denied, deferral denotes a situation of precarious balance in which a given relationship between interwoven sets of norms cannot be altered, as this would leave one or more of the involved parties deeply dissatisfied. Thriving on imprecision and ambiguity, the politics of deferral thus denotes a strategy of leaving the final arrangements between different bodies of norms open and unsettled. Finally, rather than aiming to unmake entanglements, as in the case of denial, or postponing conclusive settlements between competing sets of norms, as in the case of deferral, translation refers to the proactive transformation of norms that occurs as they move back and forth between different contexts. In all three modes - denial, deferral and translation - multiple normativities do not merely coexist but are brought to life and are related to each other through the ardent work of individual actors. They are the main protagonists of this chapter.

After having discussed the ways in which colonial legacies have historically shaped and continue to strongly affect entanglements between international, state and non-state law in postcolonial spaces (Section 2.2), I turn to the discussion of denial, deferral and translation as three distinct modes through which actors seek to navigate highly complex entangled legal landscapes (Section 2.3). The remainder of the chapter then turns to the analysis of the dynamics in which legalities become entangled in Bangladesh as a postcolonial space par excellence (Section 2.4). More precisely, I focus on three instances to illustrate these dynamics: first, the Supreme Court's attempt to ban Islamic fatwas in 2001 (denial); second, the violent protests this has triggered and the subsequent decision of the Appellate Division of the Supreme Court to stay the verdict for over a decade (deferral); and third, the work of local activists who, regardless of constitutional developments, seek to carve out emancipatory spaces for marginalized people by simultaneously drawing on multiple normative registers, including Islamic and international human rights norms (translation). 


\subsection{Colonial Entanglements}

Today's legal entanglements unfold in long historical trajectories in which colonial encounters have played a decisive role. ${ }^{3}$ On the one hand, law was a key instrument of colonial rule. It was, in the words of Martin Chanock, 'the cutting edge of colonialism, an instrument of the power of an alien state and part of the process of coercion'. As an instrument of coercion, law was crucial for the facilitation of the extraction of land, labour and mineral resources from the colonized as well as for the organization of highly unequal trade networks and market exchanges. ${ }^{5}$ Yet beyond its function as a tool for domination, Sally Engle Marry has argued that law also had constitutive effects; it not only enabled extraction but also 'transformed conceptions of time, space, property, work, marriage, and the state. ${ }^{6}$ Embedded in broader systems of domination, colonial laws thus significantly altered not only the material infrastructures of colonized societies but also deeply transformed diverse systems of knowledge deployed to navigate various aspects of everyday life. While colonial projects varied significantly across time and space, as well as between different colonizing empires, most, if not all, European colonial projects operated through the making and unmaking of legal entanglements whose shape and direction were frequently the subjects of intense debate in both the colonies and the metropoles. In these debates, arguments ranged from the wholesale transfer of metropolitan laws to the wide-ranging reliance on seemingly indigenous laws in systems of indirect rule. Yet even in the latter case, colonialism's legal entanglements had far-reaching effects on colonized societies. Rather than simply relying on pre-existing 'traditional' or 'customary' authority, colonial projects operating through various forms of indirect rule strongly altered Indigenous legal forums. Importantly, the kind of legal pluralism that emerged and continues to significantly shape legal dynamics in most of the world today was thus not a factual state of affairs but a project to be realized. As Lauren Benton argues, 'colonial powers sought simultaneously to

${ }^{3}$ For an extended version of this argument, see also T. Berger, "The "Global South" as a Relational Category: Global Hierarchies in the Production of Law and Legal Pluralism' (forthcoming) Third World Quarterly.

${ }^{4}$ M. Chanock, Law, Custom, and Social Order: The Colonial Experience in Malawi and Zambia (Cambridge University Press, 1985), p. 4.

${ }^{5}$ J. L. Comaroff, 'Reflections on the Colonial State, in South Africa and Elsewhere: Factions, Fragments, Facts and Fictions' (1998) 4 Social Identities 321-61, at 325.

6 S. E. Merry, 'Law and Colonialism' (1991) 25 Law \& Society Review 889-922, at 890-1. 
establish limited jurisdiction and to reinforce - and in some cases create Indigenous legal forums. As with indirect rule, legal pluralism as a colonial project often required the creation of "traditional" authority and the reification of legal practices and sources of law that had existed formerly only as fluid elements of a flexible legal process. ${ }^{7}$

While the constitutive effects of colonial laws on colonized societies have been carefully documented, recursive effects on the colonizing societies have received less attention. In the legal histories of Western Europe and North America, narratives of autonomous legal evolutions still predominate. Yet the constitutive effects of colonial encounters cut both ways. Although highly unequal, these encounters did not merely constitute the unilateral imposition of legal templates. Instead, recent scholarship has shown how even core aspects of European legal systems remain poorly understood if conceptualized without the transnational entanglements in which they emerged. Rather than being only peripheral to legal developments in Europe, colonies frequently had to serve as laboratories for legal innovation and new regulatory techniques. As John Comaroff has argued, 'the terrain of the colonized became a testing ground from which emanated new lawfare, new technologies of order and regulation. These sometimes confined themselves to the colonial frontier itself. But sometimes they were taken back to the metropole, there to alter its social lineaments. ${ }^{8}$ At times, the alterations that resulted from the retransfer of legal innovation to the metropole were farreaching. One example is the legal institution of property as a cornerstone of liberal social and political orders developing in Western Europe. As Brenna Bhandar has shown, the emergence and current shape of modern property laws in the United Kingdom are inseparable from colonial expansions since the eighteenth century. ${ }^{9}$ In her account, the validation of formal ownership via the registration of land titles in stateregulated regimes institutionally emerged in the colonies of South Australia and British Colombia, long before a similar regime became implemented in the United Kingdom on a national scale. ${ }^{10}$ Perhaps

7 L. Benton, Law and Colonial Cultures: Legal Regimes in World History, 1400-1900 (Cambridge University Press, 2002), p. 128.

8 J. L. Comaroff, 'Colonialism, Culture, and the Law: A Foreword' (2001) 26 Law \& Social Inquiry 305-14, at 311.

9 B. Bhandar, Colonial Lives of Property: Law, Land, and Racial Regimes of Ownership (Duke University Press, 2018).

10 Ibid., pp. 77-114. 
ironically, the subsequent prevalence of private property as a formally sanctioned, state-recognized institution became a key marker of civilizational achievements while, conversely, its absence turned into a key justificatory trope for colonial settlements. ${ }^{11}$ The ensuing 'racial regimes of ownership', as Bhandar aptly calls them, fundamentally shaped processes of social and political transformation in both the colonies and the metropoles. At an equally fundamental level, Nasser Hussain has shown how notions of the rule of law, and exceptions to this rule of law in terms of emergency powers, were at the heart of nineteenth-century colonial governance in India and Jamaica, which, in turn, decisively 'affected the development of Western legality'. ${ }^{12}$ These accounts of the entangled legalities in which modern notions of property as well as 'the rule of law' as cornerstones of legal systems emerged powerfully undermine inward-looking narratives of teleological (legal) development in either the Global North or the Global South.

\subsection{Dynamics: Denial, Deferral and Translation}

Those places where colonial powers institutionalized plural legal orders as explicit strategies for the consolidation of their rule constitute privileged sites for the investigation of entangled legalities. Here, both state and non-state law have not developed in isolation but invariably bear the traces of the transnational entanglements in which they emerged. Significantly shaping different sets of legal norms as well as the respective relationships between them, the effects of these transnational entanglements have been enduring, reaching well into the postcolonial period. In the postcolonial period, at least three different kinds of entanglements can be observed in previously colonized, plural legal orders. First, international financial institutions and multilateral donor agencies continue to entangle state legal systems transnationally. These entanglements encompass both the substantive legal provision, generally along liberal lines, and the facilitation of material legal infrastructures like courtrooms or digital devices. Contemporary transnational legal entanglements thus take myriad forms, often enumerated by international actors in terms of 'laws passed, people trained, computers

11 C. W. Mills, The Racial Contract (Cornell University Press, 1997).

12 N. Hussain, The Jurisprudence of Emergency: Colonialism and the Rule of Law (University of Michigan Press, 2003), p. 3. 
provided, buildings erected'. ${ }^{13}$ Second, transnational entanglements also continue shaping the operation of non-state legal systems. These entanglements stem from various sources, including (again) international donor organizations that have recently rediscovered non-state justice institutions as seemingly 'local' and 'authentic' avenues for the promotion of human rights and the rule of law. ${ }^{14}$ Yet diaspora communities also entangle non-state justice institutions in broader webs of conflict resolution beyond the confines of the nation state, thus embedding seemingly local courts in wider networks of normative and legal reasoning. ${ }^{15}$ Finally, state and non-state law in postcolonial contexts are not only transnationally embedded but also interact with each other. The ensuing entanglements can take various forms. They can surface as formal legal integration, for example, when non-state justice institutions are recognized by state authorities under conditions of adherence to certain substantive and/or procedural requirements. In addition, entanglements can also emerge through officials performing functions across different systems. Marlies Bouman provides a powerful example of such entanglement in her analysis of the complicity of police officers in the facilitation of non-state justice in Botswana, where "chiefly courts are in fact tolerated, or even supported, by the official police forces, although their adjudication activities are in violation of various national laws'. ${ }^{16}$ Beyond formal integration, state and non-state law thus also become entangled in quotidian practices of conflict resolution.

What emerges in these entanglements is a dynamic movement of approximation and distancing, as actors navigate the complex space in-between state and non-state law. As argued in Chapter 1, this space in-between emerges as entanglements '[are often] characterized by a dialectical dynamic - one in which actors favour proximity between different bodies of norms but they also seek a certain distance, and they

${ }^{13}$ D. Desai and M. Woolcock, 'Experimental Justice Reform: Justice for the Poor: Lessons from the World Bank and Beyond' (2015) 11 Annual Review of Law and Social Science $155-74$, at 163.

14 T. Berger, 'Global Village Courts: The United Nations and the Bureaucratization of Nonstate Justice in the Global South', in R. Niezen and M. Sapignoli (eds), Palaces of Hope: The Anthropology of International Organizations (Cambridge University Press, 2017), pp. $198-219$.

15 A. Hoque, 'Land, Development and the Political Class: In a Translocal "Londoni" Village' (2020) 54 Contributions to Indian Sociology 215-35.

16 M. Bouman, 'A Note on Chiefly and National Policing in Botswana' (1987) 19 Journal of Legal Pluralism and Unofficial Law 275-300, at 291. 
thus construe the relation as neither strict separation nor full integration into one order'. In what follows, I introduce three distinct modes in which the dynamics of entangling (and disentangling) legalities can unfold: denial, deferral and translation. Denial constitutes a radical form of distancing. It does not concern so much the repudiation of the actual existence of the entanglements of different sets of norms as empirical phenomena but denies their legal validity as much as their normative desirability. Entangled legalities are thus portrayed as pathologies to be overcome by the actors involved. In the case of entanglements between state and non-state law, denial as a way of (almost) unmaking entanglements frequently relies on teleological narratives reproducing rather than challenging idealized notions of law as a unitary and coherent system. Interestingly, the denial of one set of entanglements might well coincide with simultaneous demands for new but different entanglements. Liberal critics of the pathologies of non-state institutions, for example, often rely on international norms concerning human rights to make their case for severing the ties between state law and its local non-state counterparts. In these cases, entangled legalities are evaluated against the backdrop of a spatial imagination in which 'the international' is seen as the reservoir of normatively desirable order, whereas 'the local' becomes the source of backwardness, poverty and strife. ${ }^{17}$ State law is sought to be entangled with the former, also to distance it from the latter.

In contrast to the denial of legal entanglements, deferral aims at keeping a precarious balance between different forces in place. Often this involves undermining aspirations to unity and coherence usually associated with state law. Instead of producing certainty, the politics of deferral flourishes in the realm of the uncertain and undecided. It enables cohabitation precisely because it does not conclusively settle issues or conflicts, which cannot be settled, or cannot be settled in a way acceptable to all parties involved. Noah Salomon provides a striking example of the politics of deferral in his analysis of 'The Ruse of Law' in Sudan. Analysing the politics of religious diversity in the 1990s, he shows how, in the run-up to the 2005 Comprehensive Peace Agreement, only the suspension of the questions of applicability of Islamic religious principles to non-Muslims enabled progress in otherwise stalled negotiations between the north and the south. In Salomon's words, in the negotiations it seemed 'that the consensus was that the building of a state that respects

17 R. Rao, Third World Protest: Between Home and the World (Oxford University Press, 2010), p. 45. 
religious diversity was only possible in spite of the law - that is, when the law was unequally or inconsistently applied - and not by crafting a law that would be acceptable to all. ${ }^{18}$ Here, a unitary and consistent legal system is deliberately eschewed for inconsistency and a status of deferred legal certainty. Interestingly, the resulting uncertainty is often a source of stability rather than chaos. While scholars operating within the kind of unitary images of law outlined in Chapter 1 unavoidably understand uncertainty as a source of trouble and strife, the notion of legal entanglements opens the analytical space to appreciate the stabilizing function of uncertainty. Precisely because the conflictual relationship between different sets of norms is not brought into hierarchical order but is kept open and thus dynamic (or 'uncertain'), entangled legalities can have de-escalating effects in situations where seemingly irreconcilable differences coincide.

The third mode through which actors navigate entangled legalities is translation. Rather than aiming to unmake entanglements, as in the case of denial, or postponing specific settlements between competing sets of norms (as with deferral), translation refers to the proactive transformation of norms that occurs as they move back and forth between different contexts. Its focus is less on conceptualizing the ways in which different sets of norms are temporarily coupled or decoupled but rather on the myriad ways in which external ideas enter specific sets of norms. Translations usually involve two kinds of change that occur simultaneously. ${ }^{19}$ On the one hand, the content of norms changes, at times quite considerably. As Walter Benjamin argued in his seminal reflection of 'The Task of the Translator', translations are inherently creative as much as productive processes. Instead of simply transferring ideas from one language (or one context) into another, translations constitute proactive innovations of new meanings. This, in turn, challenges the idea of 'the original' as an authoritative reference point to which any translation would need to seek as close a proximity as possible. Instead, proximity in meaning might well arise from a seeming distance to the original. In the beautifully poetic words of Benjamin, 'no translation would be possible if, in accord with its ultimate essence, it were to strive for

${ }^{18}$ N. Salomon, 'The Ruse of Law: Legal Equality and the Problem of Citizenship in a Multireligious Sudan', in W. F. Sullivan, R. A. Yelle and M. Taussig-Rubbo (eds), After Secular Law (Stanford University Press, 2011), pp. 200-20, at p. 203.

19 T. Berger, Global Norms and Local Courts: Translating the Rule of Law in Bangladesh (Oxford University Press, 2017). 
similarity to the original. For in its continuing life, which could not be so called if it were not the transformation and renewal of a living thing, the original is changed. ${ }^{20}$ On the other hand, as the content of norms changes, the contexts in which they are translated are also altered. In processes of translation as well as in instances of denial and deferral, the boundaries of Razian legal systems, both inwards and outwards, become rather fuzzy. To illustrate the modes of denial, deferral and translation, the remainder of this chapter turns to the analysis of entangled legalities in contemporary Bangladesh.

\subsection{Entangled Legalities in Bangladesh}

As a highly transnationalized socio-political space, Bangladesh exemplifies the properties of postcolonial statehood and the correlative legal entanglements so far discussed. Since its inception Bangladesh has been a highly aid-dependent country. Labelled as a 'perpetual basket case' by Henry Kissinger in the $1970 \mathrm{~s},{ }^{21}$ it subsequently became a testing ground for development practices and ideas as well as a focal point for developmental innovations. ${ }^{22}$ At the same time, the country's legal landscape is characterized by historically grown and deeply anchored plurality. In Sarah White's paraphrase of Joel Migdal, Bangladesh remains 'a weak state in a strong society'. ${ }^{23}$ The resultant legal entanglements between international, national and local sets of norms as well as between state and non-state law unfold in a long historical trajectory reaching back to the British colonial state in India. Before turning to the analysis of three instances of denial (Section 2.5), deferral (Section 2.6) and translation (Section 2.7), I first briefly sketch some pertinent aspects of this trajectory.

Having been part of the colonial state in India, Bangladesh emerged from the so-called second partition on the Indian subcontinent. The first had resulted in the separation of India and Pakistan upon the eve of independence in August 1947. Based on the 'two-nation theory' and the

${ }^{20}$ W. Benjamin, 'The Translator's Task' (1997) 10 TTR: traduction, terminologie, rédaction $151-65$, at 155 .

${ }^{21}$ C. Bell, 'Kissinger in Retrospect: The Diplomacy of Power-Concert?' (1977) 53 International Affairs 202-16.

22 D. Lewis, Bangladesh: Politics, Economics, and Civil Society (Cambridge University Press, 2011).

23 S. White, 'NGOs, Civil Society, and the State in Bangladesh: The Politics of Representing the Poor' (1999) 30 Development and Change 307-26. 
assertion that Hindus and Muslims constituted two different nations and consequently ought to inhabit distinct nation states, Pakistan emerged as a bifurcated state with two geographically disconnected wings, separated by more than 1,000 kilometres of Indian territory. In many ways an unviable political project from the outset, tensions in Pakistan quickly rose, especially between the eastern and western wings. Escalating over questions of political representation, the distribution of resources and above all - national language, these tensions resulted in a short but bloody war of independence in 1970-1, leaving between one and three million dead and more than ten million refugees in neighbouring India. Based on an ethnolinguistic nationalism built around the Bengali language as the most decisive marker of identity for the inhabitants of what was then still East Pakistan, the independence movement sought to undermine Pakistan's raison d'être as the homeland for all Muslims on the subcontinent by advocating a secular rather than religious identity for the future state-to-be. After the surrender of the Pakistani troops, following Indian aerial intervention in December 1971, Sheikh Mujibur Rahman and the Awami League as leaders of the independence movement consequently established secularism, together with socialism, nationalism and democracy, as constitutive principles of the newly born state of Bangladesh. ${ }^{24}$

Since its inception the state of Bangladesh has existed in a web of multiple, at times overlapping, entangled legalities. From the British colonial state in India, it inherited a bifurcation between secular Civil and Criminal Codes and a set of religious personal laws governing questions of marriage, divorce, inheritance and the custody of children. While based on religious precepts, the colonial state heavily intervened in the interpretation of religion. Relying on orientalist scholarship and excessively scripture-based understandings of religion, the colonial state codified religious laws whose content diverged significantly from the quotidian practices of (religious) legal interpretation in India. As Michael Anderson has argued, 'colonial administrators may never have changed Islamic legal arrangements quite so profoundly as when they were trying to preserve them'. ${ }^{25}$ Departing from the colonial interpretation of religious law, the Pakistani state also engaged in substantial

${ }^{24}$ W. van Schendel, A History of Bangladesh (Cambridge University Press, 2009).

25 M. R. Anderson, 'Islamic Law and the Colonial Encounter in British India', in D. Arnold and P. Robb (eds), Institutions and Ideologies: A SOAS South Asia Reader (Curzon Press, 1993), pp. 165-85, at p. 169. 
religious law reform. From the Pakistani period, the postcolonial state in Bangladesh inherited the 1961 Muslim Family Laws Ordinance (MFLO). In many ways a radical piece of legislation, the MFLO altered inheritance patterns for orphaned grandchildren in ways considered by many religious authorities in direct contravention of Shar'ia law. ${ }^{26}$ Until today, this provision of the MFLO is subject to vocal protest, most recently during large-scale rallies of the Hefazat-e-Islami movement in Dhaka in 2013, demanding (in addition to twelve further points) the 'abolishment of anti-Islamic inheritance laws'. Besides altering the law of inheritance, the MFLO also established a central role for the state in the administration of Muslim family law.

It prohibits the practice of so-called 'verbal divorce' (effected by a husband uttering the word 'talaq' three consecutive times). Under the MFLO, all Muslim marriages have to be registered with the state, and any divorce of such marriage can only take effect if submitted in writing to the chairman of the local administrative council and subject to a ninety-day mediation phase aimed at the restoration of marital life. While welcomed by women's rights organizations, the MFLO provoked severe resistance among the community of religious scholars in Pakistan who understood it to be a direct attack on their authority. $^{27}$

From the liberation movement, the state inherited the initial emphasis on secularism as a foundation of the state. Yet this notion of secularism was always subject to interpretation and contestation. Between 1975 and 1991, Bangladesh was governed by two military dictatorships, both of which deployed religious language as a legitimating device. ${ }^{28}$ The first dictator, General Ziaur Rahman, changed the principle of secularism to an emphasis on 'absolute trust and faith in the Almighty Allah' in the preamble as well as a new subclause (1A) of the Bangladeshi constitution. The second one, General Husain Md. Ershad, altered the constitution in 1988 by introducing the Eighth Amendment that declared Islam to be the

${ }^{26}$ M. J. Nelson, In the Shadow of Shari'ah: Islam, Islamic Law, and Democracy in Pakistan (Columbia University Press, 2011); M. J. Nelson, 'Inheritance Unbound: The Politics of Personal Law Reform in Pakistan and India', in S. Khilnani, V. Raghavan and A. K. Thiruvengadam (eds), Comparative Constitutionalism in South Asia (Oxford University Press, 2012), pp. 219-46.

27 M. Ahmad, 'The MFLO of Pakistan' (1993) 10 International Journal on World Peace $37-46$, at $42-3$.

28 A. Riaz, "God Willing”: The Politics and Ideology of Islamism in Bangladesh' (2003) 23 Comparative Studies of South Asia, Africa and the Middle East 301-20. 
state religion. ${ }^{29}$ Ershad's amendment encountered strong resistance from both secular and religious forces within the country, as the strongest Islamic political party, the Jamaat-e-Islami, denounced Ershad's move as 'hypocritical' and 'not genuinely Islamic'..$^{30}$ A 2010 Supreme Court verdict reinstated secularism as a cornerstone of the constitution and banned Islamic parties. ${ }^{31}$ Through the following Fifteenth Amendment of the Constitution in 2011, Article 1A was deleted and replaced by Article 8 (1) stating that ' $\mathrm{t}$ ] he principles of nationalism, socialism, democracy, and secularism [...] shall constitute the fundamental principles of state policy'. At the same time, however, Article $2 \mathrm{~A}$ was left intact, declaring that ' $\mathrm{t}$ ] he state religion of the Republic is Islam, but the State shall ensure equal status and equal right in the practice of the Hindu, Buddhist, Christian and other religions'. ${ }^{32}$

Finally, the complex constitutional history also encompasses ongoing transnational entanglements in the form of obligations under international treaties. Bangladesh has signed the Convention on the Elimination of All Forms of Discrimination Against Women (CEDAW, signed in 1984), the Convention on the Rights of the Child (signed in 1990), the International Covenant on Economic, Social, and Cultural Rights (signed in 1998) and the International Covenant on Civil and Political Rights (signed in 2000), all of which have become powerful tools in the hands of Bangladeshi human rights organizations in their struggles against myriad forms of discrimination. In these struggles, local organizations need to navigate a complex web of entangled legalities, comprising a discrete set of state laws, often still exhibiting the imprint of colonial authorship, various forms of local non-state law, including religious

Ershad's amendment also further 'indigenized' national identify by changing the spelling of 'Bengali' to 'Bangla' and 'Dacca' to 'Dhaka'.

30 Riaz, 'God Willing', 308-11.

31 This decision currently seems highly controversial as in the run-up to the national elections in January 2014, the Election Commission has withdrawn the registration of the Jamaat-e-Islami. A High Court verdict from November 2013 confirmed the deregistration of the Jamaat-e-Islami. The judges argued that although Islam is the state religion under article (2A), 'the Jamaat had misinterpreted Islam from its inception' (quoted in The Dhaka Tribune, 4 November 2013).

32 Constitution of the People's Republic of Bangladesh, P.O. No. 76 of 1972, 4 November 1972, website of the Bangladeshi Ministry of Law, http://bdlaws.minlaw.gov.bd/sections detail.php?id=367\&sections_id=24549, accessed 7 November 2013. This is the slightly altered version of 2011. The earlier version from $1988 \mathrm{read}$ : ' $\mathrm{t}$ ] he state religion of the Republic is Islam, but other religions may be practiced in peace and harmony in the republic'. Quote taken from www.law.emory.edu/ifl/legal/bangladesh.htm, accessed on 7 November 2013. 
precepts and customary conventions, and a liberal international architecture at least partially anchored in state law.

In what follows, I analyse denial, deferral and translation as three modes in which human rights organizations seek to navigate these entanglements. To scrutinize these processes of entangling and disentangling legalities, I focus in particular on the question of the legal status of fatwa. While the precise definition of fatwa is itself subject to ongoing debates, at its most basic fatwa refers to a non-binding decision issued by a learned religious authority on a point of Islamic law or practice. ${ }^{33}$ Yet who exactly qualifies as a learned scholar authorized to issue fatwa, the weight of fatwa in light of competing legal precepts and the precise scope of which kinds of questions are actually governed and governable under Islamic law remain subjects of contention, and not only in Bangladesh. ${ }^{34}$ In Bangladesh, these questions gained judicial salience with a High Court judgement issued in 2001.

\subsection{Denial}

On 1 January 2001, a Division Bench of the High Court Division of the Supreme Court of Bangladesh delivered what many national and international observers at the time considered to be a landmark judgement. On its own initiative and without having been approached by any party, the court has issued a suo moto ruling in reaction to a news item reported in the Bangladeshi newspaper Daily Bangla Bazar Patrika on 2 December 2000. The ruling questioned local authorities of Naogaon district regarding their failure to act against an illegal fatwa. The fatwa had directed a young woman of Naogaon to undertake an intervening marriage after an alleged verbal divorce to restore marital life with her previous husband. According to the news report, Saiful Chunnu of Naogaon village had pronounced 'talaq' ('divorce') to his wife Shahid more than a year ago, yet the couple had reconciled and continued marital life. As Saiful Chunnu spent a few days away from their village on family business, a neighbour claimed to have heard the pronouncement of 'talaq' and issued a fatwa directing Shahid to undergo a so-called

33 D. Siddiqi, 'Islam, Gender, and the Nation: The Social Life of Bangladeshi Fatwas', in D. Heath and C. Mathur (eds), Communalism and Globalization in South Asia and Its Diaspora (Routledge, 2011), pp. 181-203, at pp. 200-1.

34 W. B. Hallaq, The Impossible State: Islam, Politics, and Modernity's Moral Predicament (Columbia University Press, 2013). 
hilla (intervening) marriage with another man from the village. Upon his return and learning about the forced hilla marriage, Saiful Chunnu refused to continue their marriage and sent Shahid back to her father's house. While highlighting the persistence of patriarchal power relations, the case is rather unambiguous in the legal terms of the state. Both intervening hilla marriages and verbal divorce (whether by uttering 'talaq' once or thrice) are in violation of Section 7 of the MFLO; in addition, causing people to believe that they will become objects of Divine displeasure is punishable under Section 508 of the Penal Code. ${ }^{35}$ The court's condemnation of the local authorities' failure to act is thus neither surprising nor controversial.

While singling out the fatwa case from Naogaon, the court's verdict unfolds against the backdrop of deeper societal controversies over fatwa practices. As Dina Siddiqui has shown, since the early 1990s approximately thirty-five to sixty fatwa cases have annually gained attention in the national press. ${ }^{36}$ This does not mean that fatwa are a recent phenomenon; it only indicates the increased visibility of certain kinds of fatwa verdicts after the return to electoral democracy in 1990 and the correlative improvements in freedom of speech. The fatwa cases that attract the attention of a larger audience often involve extreme displays of violent enforcement, frequently targeted against women's bodies. One of the first fatwa cases discussed at the national level was the case of Nurjahan in 1993. After having obtained a divorce from her first husband, Nurjahan rejected the proposal of an influential member of the village community and decided, instead, to marry a landless youth of her choice. Enraged by the refusal, the influential village elder initiated a shalish court and prompted a local religious figure to issue a fatwa against Nurjahan and her second husband for adultery. Although the same figure had previously verified the state-sanctioned divorce of Nurjahan and her first husband, he subsequently disputed the validity of the divorce papers produced in the shalish session, in which Nurjahan, her husband and the guests attending their wedding party were condemned to acts of severe public humiliation. Based on her meticulous reconstruction of the complexity of local power structures, Dina Siddiqui has shown how

35 F. Pereira, 'Introduction' (2002) 4 Interventions 212-14; S. Hossain, 'High Court Nails Fatwa' (2002) 4 Interventions 220-3; A.-U. Zaman, 'Fatwa and the High Court' (2002) 4 Interventions 233-6.

36 D. Siddiqi, 'Crime and Punishment: Laws of Seduction, Consent, and Rape in Bangladesh' (2011) 1 Social Difference Online 46-54, at 47. 
Nurjahan's case cannot be read exclusively through the lens of seeming adherence to religious moral precepts. Instead, she shows how the fatwa aims to reaffirm intersecting power structures, including patriarchal control and class domination. ${ }^{37}$ Yet these complexities are frequently lost in both liberal international and secular-nationalist narratives of fatwa violence. As Siddiqui argues, in Bangladesh:

Understandings of the 'fatwa-frenzy' were also overdetermined by the specific trajectory of secular nationalism [...], in which Islam had always been the Other of the nation. Within this context, fatwas came to signify the contamination of secular national space by the backwardness of religious law. Accordingly, fatwas could be read as antinational phenomena attached to Islam, rather than one located in the complex conditions of modernity. ${ }^{38}$

It is this broader discursive universe, in which questions of fatwa verdicts intimately link to questions of national identity and the legacies of the liberation movement that the High Court's verdict is articulated in January 2001.

As argued earlier in this section, the verdict against the specific fatwa under scrutiny seems neither surprising nor especially controversial. Much more controversial than the condemnation of the individual case, however, were the broader implications that the court sought to extrapolate from the case it had decided to pursue. First, it concluded that all fatwa are illegal. As the court argued: 'Fatwa means legal opinion which, therefore, further means legal opinion of a lawful person or authority. [The] [1]egal system of Bangladesh empowers only the Courts to decide all questions relating to legal opinion on the Muslim and other Laws as in force. We, therefore, hold that any fatwa including the instant one are all unauthorised and illegal. ${ }^{39}$ Furthermore, the court called upon parliament to make the issuing of fatwa a punishable offence, even if the fatwa was not executed. In addition, the court's verdict also recommended the inclusion of the (until today highly controversial) MFLO in the Friday sermons and argued for the creation of a unitary education system, including religious educational institutions:

37 Siddiqi, 'Islam, Gender, and the Nation', p. 189.

38 D. Siddiqi, "Transnational Feminism and "Local" Realities: The Imperiled Muslim Woman and the Production of (In)Justice' (2011) 9 Hawwa 76-96, at 81.

39 Quoted in the Daily Star Law Report, 7 January 2001. Reproduced in 'The Fatwa in Question Is Wrong' (2002) 4 Interventions 228-32, at 231. 
Before parting with this matter, we find it necessary to answer a question as to why a particular group of men, upon either getting education from maddrasah or forming a religious group, are becoming fanatics with wrong views. There must be defect in their education and their attitude. As a short measure, we recommend that study of Muslim Family Laws Ordinance must be introduced in all schools and that the Khatibs in all the mosques must be directed to discuss the Ordinance in their Friday sermons. As a long-term measure, we recommend an unified education system and an enactment to control the freedom of religion subject to law, public order and morality within the scope of Article 4 (1) of the Constitution. The State must define and enforce public morality. It must educate society. ${ }^{40}$

In effect, this line of argument amounted to a hardly concealed attack on entrenched religious authorities and their standing within established local power structures. Rather than limiting itself to the already justiciable prosecution of the violence inflicted under the seeming cover of religious justification, the verdict constitutes a radical attempt at affirming the superiority of the state over societal sources of law and legal reasoning tout court. What is remarkable about the case decided on 1 January 2001 is thus neither the indictment of the inaction of local state authorities nor the condemnation of the individual fatwa but the vehemence with which it draws much broader conclusions about the relationship of state and nonstate law, especially in its religious manifestations. By calling upon the state to enforce public morality and educate society, it seeks to disentangle the complex legal architecture of family relations, especially in rural parts of the country, from religious influences. This denial as a radical form of distancing, which aims at the creation of the greatest distance possible between entangled legalities, unsurprisingly encountered strong resistance. Demanding the subordination of state law to religious principles, several Islamic organizations, including both political parties and religious educational institutions, organized a general strike, disrupting public life and leading to violent confrontation with law enforcement agencies. Religious scholars also appealed the judgement in the Appellate Division of the Supreme Court. The Supreme Court, in turn, stayed the verdict exactly two weeks after it had been first pronounced. Attempts at denying the entanglements between the state laws and religious authorities (however defined) had come to a standstill. What emerged, instead, was a politics of deferral.

${ }^{40}$ Ibid. 


\subsection{Deferral}

After the Supreme Court had stayed the verdict in January 2001, initially for a mere six weeks, it took more than a decade before the legal status of fatwa was to reappear at the court. Confronted with hardened positions between secular-nationalist and religious camps, the court decided not to pursue the case further. Instead of aiming for legal clarity, the court settled for a politics of deferral where the legal status of fatwa remained undecided. Initially, the deferral coincided with a change in political climate. While the original judgement was passed during the last days of the Awami League-led government, in October 2001 the Bangladesh Nationalist Party (BNP), in coalition with three smaller parties, including religious ones, won the elections. Although recent scholarship has shown how the ideological differences between the Awami League and the BNP seem exaggerated in both public imagination and scholarly discourse, ${ }^{41}$ the BNP's return to power in 2001 did amplify the voice of small yet highly organized Islamic political parties. Operating in a precarious balance of different political forces, the erstwhile very vocal defendants of the so-called 'fatwa ban' settled for a strategy of deferral, especially at the constitutional level. While the case seemed to be lingering and almost forgotten, its deferral was actually not caused by inaction but hard work, requiring myriad interventions to make sure that no judgement was forthcoming. One close observer and longstanding participant in the judicial contestation over the status of fatwa summarized the politics of deferral that emerged as follows:

And then [after the Supreme Court had stayed the verdict in 2001], we ran a ten-year job to make sure that this case did not get heard too early, because at various points there were very worrying constructions of the bench and so on - and we were worried that if the case got heard that we would end up with a Supreme Court finding [...] saying that there is a fundamental right to issue fatwa. ${ }^{42}$

The decision on the constitutional status of fatwa thus remained undecided - until 2011.

In 2011, the Appellate Division of the Supreme Court reopened the case and endorsed, at least in part, the appeal that had been filed against the initial High Court verdict on the illegality of fatwa. Contra the High

${ }^{41}$ M. Hassan and S. Nazneen, 'Violence and the Breakdown of the Political Settlement: An Uncertain Future for Bangladesh?' (2017) 17 Conflict, Security \& Development 205-23.

42 Interview by author with senior legal counsel, Dhaka, January 2012. 
Court judgement, it declared fatwa legal, but only if it was (1) passed by a 'learned person', and (2) only applied to 'religious matters'. Yet on both of these important qualifications the judgement remained conspicuously vague. It neither defined the ingredients necessary to qualify as a 'learned person' nor delineated what precisely constituted a 'religious matter'. The ambiguity surrounding the judgement further increased as the Supreme Court did not publish the full judgement until 2015, forty-four months after the verdict had been actually passed and communicated as a brief statement. ${ }^{43}$ When the full judgement was eventually published, it still refrained from these crucial specifications of what qualifies 'properly educated persons' to issue fatwa in 'religious maters', and what exactly these religious matters comprised. Even as the Supreme Court formerly settled the case, the politics of deferral thus continued, as the precise status of fatwa within the complex legal architecture of Bangladesh remained an unsettled question and open to competing interpretations.

While deferring the conclusive settlement on the constitutional status of fatwa required the continuous work by the parties involved in the case, it also allowed human right's activists to disentangle the legal condemnation of violence against women from broader questions about the status of religious law. While these broader questions remained deferred, the judgement nonetheless explicitly stated that 'no punishment including physical violence or mental torture in any form can be imposed or implicated on anybody in pursuance of [a] fatwa. ${ }^{44}$ The Supreme Court's judgement thus overturned the High Court's decision to ban fatwa in 2001 but upheld another High Court decision from 2010 on the illegality of extrajudicial punishment. This 2010 High Court decision, in turn, came in response to three writ petitions filed by five prominent human rights organizations in Bangladesh, the Bangladesh Legal Aid and Services Trust, Ain-oShalish Kendro, Bangladesh Mahila Parishad, BRAC and Nijera Kori. These organizations are exceptionally skilful socio-legal actors, and their strategic choices have paved a distinct pathway to legal entanglement. Most of the organizations had already been at the forefront of the judicial process leading to the fatwa ban in 2001. A decade later, their

43 A. Sarkar, 'Fatwa Must Not Violate Laws, SC Says in Full Verdict', Daily Star, 26 January 2015, www.thedailystar.net/fatwa-must-not-violate-laws-61702.

${ }^{44}$ Quoted in T. Huda, 'Zero Tolerance for Fatwas that Violate Human Rights', Daily Star, 23 December 2017, www.thedailystar.net/opinion/human-rights/zero-tolerance-fatwasviolate-human-rights- 1509055 . 
writ petitions constitute an attempt at disentangling the inflection of violence, often against women, from questions of Islam and Islamic law. Starting from the observation that the first judgement declaring fatwa illegal was 'very poorly reasoned', one human rights activist describes how these five organizations at the time 'thought that somehow we had to clarify this whole question: what is a fatwa, what is not a fatwa, and what is the nature of this violence? And to bring the conversation, the discussion, the judicial exercise back to a discussion about the constitution and law, rather than religion and religious rights. We had to take it out of that space. ${ }^{45}$ Taking the violence perpetrated against women out of the space of contestations over religious-cum-legal authority is an act of disentanglement. It aims to dissociate the pathologies of patriarchal power structures in Bangladesh from questions of religious rights within a constitutional framework. At the same time, while disentangling questions of violence and questions of fatwa, the argumentative architecture built carefully by the five human rights organizations did include new entanglements with international norms. As the activist already cited argues, in the final court hearing the organizations were very careful to advance the following argument:

we as Bangladeshi organisations working in Bangladesh within the framework of the Bangladesh constitution, but also within the framework of International Human Rights obligation that pertain on our government, have this interpretation. Our interpretation is that we want to have a very clear condemnation of the violence perpetrated in the name of fatwa. We do not want a debate what is and is not fatwa under religious law, we are not before a religious court, but before a constitutional court, so we want a constitutional interpretation. Our constitution clearly says: all forms of cruel and degrading punishment are prohibited. ${ }^{46}$

This argument, in turn, was supported by frequent references to CEDAW and its strict condemnation of all kinds of cruel and degrading punishments. The making and unmaking of legal entanglements in this case illustrates the importance of strategic choices of individual actors. As outlined in Chapter 1, strategic choices constitute one of the possible pathways in which entangled legalities come about. In this case, entangling and disentangling legalities coincided as Bangladeshi human rights organizations very deliberately sought to forge certain connections while releasing others.

45 Interview by author with senior legal counsel, Dhaka, January 2012.

46 Ibid. 


\subsection{Translation}

The processes of distancing and approximation analysed as 'denial' and 'deferral' in Sections 2.5 and 2.6 play out in a context of confrontation between secular-nationalist and Islamic narratives deployed by different actors to lay claims upon the state and its constitutional order. At times, these claims have been laid quite violently, for example, in the repeated physical attacks on secular women's rights NGOs by seemingly religious actors throughout the 1990s or in the equally violent crackdown on members of the Jamaat-e-Islami by the seemingly secular Awami League government in the run-up to the 2014 election. While the dividing line between the religious and the secular is frequently staged in exceedingly violent spectacles in Bangladesh, recent scholarship has cast serious doubts on the social embeddedness of this divide. Analysing the confrontation between religious actors and secular NGOs over questions of women's economic empowerment in rural areas throughout the 1990s, Sarah White has shown how 'the substance of the NGO-"Mullah" confrontation lay indeed in the symbolic, or political, capital that each side could derive from it, rather than this signifying any more structural antagonism between "Islam" and the expansion of women's economic activity. ${ }^{47}$ Analysing the multifaceted dynamics of entangled legalities in rural Bangladesh thus requires moving beyond the confines of both secular and religious elite discourses as they circulate in Dhaka's higher judicial institutions and national media outlets. In contrast to urban elites, the grassroots-level fieldworker and activists in rural Bangladesh often need to navigate significantly more complex legal landscapes that eschew dichotomous confrontations between Islam and secular nationalism. $^{48}$

To carve out emancipatory spaces for poor and marginalized people, and women in particular, activists in rural Bangladesh simultaneously draw on multiple, often quite different, normative registers. While the upper echelons of Bangladesh's vibrant NGO sector frequently disregard piety and religious registers as tools for local struggles, Elora Shehabuddin has shown how grassroots-level staff of these organizations regularly draw on religious arguments in their everyday work. The

${ }^{47}$ S. C. White, 'Beyond the Paradox: Religion, Family and Modernity in Contemporary Bangladesh' (2012) 46 Modern Asian Studies 1429-58, at 1441.

48 E. Shehabuddin, Reshaping the Holy: Democracy, Development, and Muslim Women in Bangladesh (Columbia University Press, 2008), p. 30. 
examples she cites range from Islamic condemnations of violence against women (for example by invoking the example of the Prophet Mohammed) to religious sanctions for girls' education and the use of contraception. ${ }^{49}$ Often materially dependent on international funding, this kind of grassroots-level activism in rural Bangladesh thus needs to straddle the normative expectations of very different audiences. Elsewhere, I have argued that the notion of translation offers a productive way to capture the work local activists do in their attempts to straddle these different normative expectations as well as the different legal systems in which these expectations are embedded. ${ }^{50}$ Rather than distancing or approximation, the notion of translation refers to the transformation of legalities that occurs as norms move back and forth between different contexts where they become embedded in deep webs of preexisting institutions, practices and normative aspirations. In what follows, I use this notion of translation to illustrate a third mechanism by which different legalities become entangled.

I analysed a series of such translations between 2011 and 2012 throughout my field research on the recursive interactions between transnational liberal norms and local non-state justice institutions in Bangladesh. ${ }^{51}$ Responding to a growing fatigue with conventional rule of law reform programmes that exclusively target state institutions, mostly in the Global South, non-state justice institutions have recently reappeared on the agenda of international donor organizations as one possible avenue for the promotion of human rights and the rule of law. One of the largest projects this recent interest in non-state justice institutions has given rise to aims at 'activating' the village courts in Bangladesh. The village court is a quasi-formal institution whose setup and operational logic closely resembles the non-state institution of the shalish. Yet, in contrast to the shalish, the state does recognize the village courts as legitimate sites for the trial of minor civil and criminal cases if they adhere to certain procedural requirements laid down in the 2006 Village Court Act. This focus on civil and criminal cases renders the village courts a seemingly secular institution, as in Bangladesh (like in India and Pakistan) the respective Civil and Criminal Codes are based on secular law, whereas Family Law is based on religious sources codified by the state, for example, in the MFLO discussed in Section 2.4. As several

\footnotetext{
49 Ibid., p. 102.

50 Berger, Global Norms and Local Courts.

51 Ibid.
} 
representatives of international donor agencies confirmed throughout my fieldwork, one key attraction of the village courts as sites for interventions was precisely their seeming ability to bypass the entire 'fatwa problematique' discussed in Sections 2.5 and 2.6. ${ }^{52}$ As they understood the village courts as quasi-formal institutions dealing with conflicts governed by secular law, they simply did not expect religious arguments or religious authorities to figure prominently in their project activities.

Contra their expectations, religion did figure prominently as the fieldworkers and court assistants employed by local NGOs at grassroots levels for the implementation of the project regularly engaged in vivid religious argumentations. Many of these argumentations involved women's standing in processes of conflict resolution, which - in turn - frequently escaped neat distinctions between civil, criminal and family disputes. Often, questions of physical insult or disputes over land ownership are intimately tied to family conflicts, rendering distinctions between different sets of state law difficult in practice. In reality, religious lines of argument played important roles as the resolution of conflicts falling under civil or criminal law repeatedly required the simultaneous intervention in disputes within the realm of family law. In these interventions, religious arguments were drawn upon. In the case of fatwa, for example, many fieldworkers and court assistants argued that local religious authorities lacked the training to give binding interpretations of Islamic law. Similarly, they emphasized the religious obligation of husbands to issue security payments before marrying their wives (morhana) and maintained that verbal divorces without the state-prescribed ninety-days mediation phase were, in fact, 'Un-Islamic'. Ironically, while international donor agencies sought to strengthen quasi-formal institutions for the resolution of civil and criminal conflicts, the fieldworkers and court assistants implementing the project argued, in many ways, that only the state had both the authority and the legitimacy to interpret Islamic family law. These acts of translation entangle international and local legalities in novel ways, thus allowing grassroots-level employees of Bangladeshi NGOs to carve out participatory spaces for women in a discursive environment otherwise characterized by a dichotomous confrontation between Islam and secular nationalism.

52 Interview by author with representative of the United Nations Development Program, Dhaka, March 2012. 


\subsection{Conclusions}

As a paradigmatic developing country, Bangladesh exemplifies the complexities of legal entanglements as they unfold in most of the world. Indeed, as argued in Chapter 1, the ideal type of closed, coherent and unitary legal systems that carefully guard their boundaries with clearly defined reception norms while ordering internal plurality hierarchically and unambiguously has been historically the exception rather than the rule. Navigating complex and contradictory legal landscapes often requires the mastery of 'straddling practices', in which the boundaries between different sets of norms loosen at the edges and become more fuzzy. As I have argued in this chapter, the conditions of postcolonial statehood are highly conducive to zooming in on these fuzzy rather than clearly demarcated boundaries between different legal systems. Theorizing legal entanglements from the postcolonial space of Bangladesh, I have identified three distinct modes in which actors seek to forge specific entanglements between different sets of norms. In the case of denial, empirically existing entanglements are acknowledged while their normative and legal validity is denied. Deferral as a mode of entanglement eschews fixity and, instead, thrives on ambiguity and imprecision. Here, the precise relationship between different sets of norms is deliberately left open by postponing a conclusive verdict on their hierarchical order. In contrast to legal theorists who equate imprecision with disorder and instability, the empirical excavation of processes of continued deferral as a mode of entanglement in Bangladesh has shown how it actually can become a source of stability in situations where a given relationship between different sets of norms should not be altered without leaving at least one party deeply dissatisfied. Yet, as I have shown, also keeping the final arrangements between competing sets of norms unsettled requires continued and ardent work; the mere fact that nothing seems to change is no indication of inaction but is instead the product of continued legal labour by multiple actors, in the case at hand primarily NGOs and representatives of religious institutions. Like denial and deferral, translation as a mode of entangling legalities also depends on the proactive work of individual actors. In translations, the content of norms is transformed as they move back and forth between different contexts. While resonating in the receiving context, translations nonetheless retain the mark of the foreign, thus constituting a particular kind of entanglement in which norms are neither fully integrated nor wholly kept apart but made recognizable across different 
contexts. Denial, deferral and translation constitute different pathways to legal entanglements. As I have shown in this chapter, social and legal conflicts do not, as frequently assumed in legal scholarship, unfold as disputes over the precise meaning and interpretation of individual legal norms. Instead, they also, and often even primarily, unfold as contestations over which of these pathways to take. 